\title{
PERBEDAAN KADAR GLUKOSA DARAH ATLET SETELAH LATIHAN ANTARA PEMBERIAN SARI TEBU DAN MINUMAN BERKARBOHIDRAT PABRIKAN
}

\author{
Ahmad Thohir Hidayat, Deny Yudi Fitranti*) \\ Program Studi Ilmu Gizi Fakultas Kedokteran Universitas Diponegoro \\ J1.Dr.Sutomo No.18, Semarang, Telp (024) 8453708, Email : gizifk@ undip.ac.id
}

\begin{abstract}
Background : Regulating carbohydrate intake in athlete is very important to keep a good performance. Carbohydrate consumption after exercise is used for resynthesis body's carbohydrate. The easiest way for consuming carbohydrate after exercise is consumption of carbohydrate drink. Sugarcane juice is a popular natural carbohydrate drink beside manufacturer carbohydrate drink. However, research on the difference on athlete's blood glucose level after exercise of ingestion sugarcane juice in comparison to manufacturer carbohydrate drink is limited.

Purpose : The present investigation was to study the difference on athlete's blood glucose level after exercise of ingestion sugarcane juice in comparison to manufacturer carbohydrate drink.

Methode : An quasi experimental studiy was done in randomized pretes-post test 2 group design. The subject were 20 soccer player age 13-16 years old at Sekolah Sepek Bola UNDIP in August 2014. The control group consumed Manufacturer carbohydrate drink and the treatment group consumed sugarcane juice. The amount of fluid given is $550 \mathrm{ml}$ each. Blood glucose level is checked before execise, after axercise and after intervention. The exercise was a $2.4 \mathrm{Km}$ running.

Result : Based on paired t test Both group showed significant increase on blood glucose level in both group after exercise and after ingestion of the fluid ( $p<0.05)$. Based on independent t test no significant diference $\Delta$ mean post exercise and post intervention showed between group $(p>0.05)$.

Conclusion : Ingestion of sugarcane juice and manufacturer carbohydrate drink after exercise can increase athlete's blood glucose level after exercise $24.2 \pm 28.61$ and $15.10 \pm 8.69$ each. Ingestion of sugarcane juice can increase athlete's blood glucose level as good as ingestion of commercial carbohydrate drink ( $p>0.05)$. Sugarcane juice is equally effective as carbohydrate drink after exercise in comparison to manufacturer carbohydrate drink.
\end{abstract}

Keywords : Sugarcane Juice; Blood Glucose Level

\begin{abstract}
ABSTRAK
Latar Belakang : Pengaturan asupan karbohidrat atlet sangat penting agar dapat menjaga performa. Konsumsi sumber karbohidrat setelah latihan berguna untuk mengembalikan simpanan karbohidrat tubuh atlet yang hilang. Salah satu cara yang dianggap praktis untuk menyediakan asupan karbohidrat setelah latihan adalah dengan mengonsumsi minuman berkarbohidrat. Sari tebu merupakan cairan alami sumber karbohidrat yang sering dikonsumsi selain minuman berkarbohidrat pabrikan. Meskipun sering dikonsumsi, penelitian mengenai perbedaan kadar glukosa darah atlet setelah latihan antara sari tebu dan minuman berkarbohidrat pabrikan belum banyak dilakukan.
\end{abstract}

Tujuan : Penelitian ini bertujuan untuk mengetahui perbedaan kadar glukosa darah atlet setelah latihan antara pemberian sari tebu dan minuman berkarbohidrat pabrikan..

Metode : Studi eksperimental semu dengan pendekatan randomized pretest- post test 2 group design dengan 2 kelompok perlakuan pada 20 atlet sepak bola Usia 13- 16 tahun di Sekolah Sepak Bola UNDIP pada bulan Agustus 2014. Kelompok kontrol mengonsumsi minuman berkarbohidrat pabrikan, sedangkan kelompok perlakuan mengonsumsi sari tebu murni. Jumlah masing - masing cairan yang diberikan adalah 550 ml. Pemeriksaan kadar glukosa darah dilakukan 5 menit sebelum latihan, 5 menit setelah latihan dan 15 menit setelah intervensi. Latihan yang dilakukan berupa lari $2.4 \mathrm{~km}$ dalam waktu 10.49 - 12.10 menit.

Hasil : Berdasarkan uji paired t test terdapat perbedaan yang signifikan antara kadar glukosa darah subjek setelah latihan dan setelah intervensi pada kedua kelompok baik pada kelompok kontrol maupun pada kelompok perlakuan ( $p<0.05)$. Berdasarkan uji beda independent $t$ test tidak terdapat perbedaan yang signifikan antara selisish kadar glukosa darah setelah latihan dan setelah intervensi antara kelompok kontrol dan perlakuan ( $p>0.05)$.

Kesimpulan : Konsumsi sari tebu murni dan minuman berkarbohidrat pabrikan setelah latihan mampu meningkatkan kadar lukosa darah atlet setelah latihan masing - masing sebesar $24.2 \pm 28.61$ dan 15.10 \pm 8.69. Sari tebu mampu meningkatkan kadar glukosa darah atlet sebanding dengan minuman berkarbohidrat pabrikan dengan (p>0.05). Sari tebu dapat digunakan sebagai alternatif penyedia asupan karbohidrat setelah latihan yang sama baiknya dengan minuman berkarbohidrat pabrikan.

Kata Kunci : Sari Tebu; kadar Gula Darah

\footnotetext{
${ }^{*}$ Penulis Penanggungjawab
} 


\section{PENDAHULUAN}

Prestasi seorang atlet sangat dipengaruhi oleh performa atlet itu sendiri. Performa terbaik atlet harus terus dijaga selama pertandingan maupun latihan. Performa atlet berhubungan dengan berbagai hal, yaitu kemampuan yang dimiliki, psikologi atlet saat bertanding, kebugaran tubuh atlet, latihan yang dilaksanakan sebelum pertandingan dan pengaturan gizi atlet. ${ }^{1}$ Pengaturan gizi yang tepat dapat meningkatkan performa atlet, terutama pengaturan asupan karbohidrat sebagai salah satu sumber energi dalam tubuh selain lemak dan protein. ${ }^{2}$ Pada saat simpanan karbohidrat dalam tubuh berupa glukosa darah, glikogen hati dan glikogen otot menurun dan terjadi penumpukan asam laktat setelah latihan maka akan terjadi

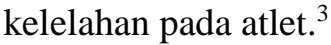

Tersedianya glukosa darah segera setelah latihan sangat penting bagi atlet agar dapat mengembalikan simpanan glikogen hati dan otot dan mengatasi kelelahan. Asupan karbohidrat segera setelah latihan atau pertandingan akan membantu mengembalikan ketersediaan glukosa darah untuk proses resintesis glikogen. Resintesis glikogen otot tertinggi adalah ketika karbohidrat dalam jumlah besar ( 1 hingga $1.85 \mathrm{~g} / \mathrm{KgBB} / \mathrm{jam}$ ) dikonsumsi segera setelah latihan. ${ }^{4}$ Penundaan asupan karbohidrat 2 jam setelah latihan dapat mengakibatkan penurunan pembentukan glikogen otot hingga 50\%.5 Setelah latihan terjadi peningkatan transport glukosa yang membantu proses resintesis glikogen, namun akan menurun secara cepat jika tidak ada asupan karbohidrat. Oleh karena itu asupan karbohidrat segera setelah latihan sangat penting agar kadar glukosa darah dan simpanan glikogen dapat dikembalikan pada nilai normal. 6,7

Selama dan setelah latihan atau pertandingan, atlet akan menghasilkan panas yang ditimbulkan oleh kontraksi otot saat berolahraga. ${ }^{8}$ Ketika suhu tubuh meningkat, nafsu makan menurun, dan sulit untuk langsung mengkonsumsi makanan kaya karbohidrat segera setelah latihan sehingga diperlukan sumber asupan karbohidrat lain selain makanan. Alternatif cara menyediakan asupan karbohidrat setelah latihan adalah dengan menggunakan minuman yang mengandung karbohidrat. ${ }^{2,9}$ Minuman sumber karbohidrat dapat diperoleh dari sumber alami maupun sintesis. Sumber alami minuman yang mengandung karbohidrat salah satunya adalah sari tebu. ${ }^{10}$

Sari tebu memiliki kandungan karbohidrat lebih tinggi dibandingkan minuman berkarbohidrat pabrikan yang umumnya hanya mengandung $6-8$ $\%$ karbohidrat. Sari tebu memiliki kandungan karbohidrat hingga 9\%, jumlah tersebut sesuai dengan kebutuhan asupan karbohidrat atlet setelah latihan yaitu $5-10 \% .{ }^{10}$, dengan jumlah kandungan tersebut kebutuhan minimal atlet usia 13 - 16 tahun setelah latihan dengan intensitas sedang yaitu $50 \mathrm{~g} /$ jam dapat dipenuhi dengan mengkonsumsi $550 \mathrm{ml}$ sari tebu. ${ }^{11}$ Kandungan karbohidrat terbesar pada sari tebu sama dengan kandungan terbesar pada minuman berkarbohidrat pabrikan yaitu sukrosa. Pada beberapa penelitian disebutkan bahwa tingkat resintesis glikogen sama baik pada saat konsumsi glukosa maupun sukrosa. ${ }^{5}$ Penelitian yang dilakukan di Eropa menyebutkan bahwa kecepatan resintesis glikogen lebih tinggi dengan pemberian minuman yang mengandung karbohidrat segera setelah latihan dibanding dengan menunda asupan karbohidrat. ${ }^{12}$

Sari tebu merupakan cairan alami sumber karbohidrat yang sering dikonsumsi di daerah tropis dan subtropis. ${ }^{10}$ Selain memiliki kandungan karbohidrat yang cukup tinggi sari tebu juga mengandung vitamin dan mineral. ${ }^{19}$ Sari tebu juga memiliki sifat antioksidan yang mampu mencegah peroksidasi lemak, mencegah oksidasi besi dan menangkap radikal bebas karena kandungan fenol dan flavonoid yang terkandung didalamnya. ${ }^{20}$ Meskipun sering dikonsumsi, penelitian mengenai perbedaan kadar glukosa darah atlet setelah latihan antara pemberian sari tebu dan minuman berkarbohidrat pabrikan belum banyak dilakukan. Penelitian ini bertujuan untuk mengetahui perbedaan kadar glukosa darah atlet setelah latihan antara pemberian sari tebu dan minuman berkarbohidrat pabrikan sebagai penunjang pemulihan performa pada atlet setelah melakukan latihan.

\section{METODE PENELITIAN}

Penelitian dilakukan di Sekolah Sepak Bola UNDIP (SSB UNDIP) pada bulan Agustus 2014. Penelitian ini merupakan penelitian quasi experimental dengan pendekatan randomized pretest - post test 2 group design dan termasuk dalam ruang lingkup gizi olah raga. Subjek penelitian adalah atlet sepak bola dengan kriteria inklusi berusia 13- 16 tahun yang berada di SSB UNDIP, indeks massa tubuh normal, tidak sedang cedera atau dalam perawatan dokter, memiliki tingkat kebugaran kategori cukup yang diukur dengan metode cooper, cukup tidur sebelum penelitian, tidak memiliki riwayat penyakit berhubungan dengan jantung, nadi, paru- paru atau diabetes dan kadar glukosa darah sewaktu sebelum latihan normal $(70-150 \mathrm{mg} / \mathrm{dl})$ serta bersedia mengikuti penelitian melalui persetujuan Informed 
Consent. Subjek akan dikeluarkan dari penelitian bila tidak mengikuti setiap tahap penelitian, sakit atau mengalami cedera pada saat penelitian berlangsung, mengonsumsi minuman karbohidrat selain yang diberikan oleh peneliti selama penelitian berlangsung, mengonsumsi suplemen yang berfungsi sebagai pembangkit tenaga sesaat sebelum dan selama penelitian berlangsung, dan memiliki kadar glukosa darah sewaktu sebelum latihan $>150 \mathrm{mg} / \mathrm{dl}$. Penelitian ini telah mendapat izin ethical clearence.

Terdapat 2 kelompok perlakuan pada penelitian ini yaitu kelompok kontrol dan kelompok perlakuan. Jumlah sampel minimal yang diperlukan adalah 9 orang tiap kelompok dengan antisipasi drop out sebesar $10 \%$ menjadi 10 orang untuk tiap kelompok. Jumlah tersebut ditentukan dengan menggunakan rumus perkiraan besar sampel dua kelompok independen. Terdapat 22 orang dari populasi yang memenuhi kriteria inklusi penelitian, 20 orang bersedia menjadi subjek penelitian. Pembagian subjek menjadi dua kelompok ditentukan dengan menggunakan teknik simple random sampling yaitu pengambilan sampel anggota populasi dilakukan secara acak, dimana setiap subjek dalam populasi terjangkau memiliki kesempatan yang sama untuk terpilih atau tidak terpilih sebagai sampel.

Variabel bebas pada penelitian ini adalah sari tebu murni yang diperoleh dari tebu jenis Ps. Sari tebu diperoleh dengan menggiling batang tebu hingga mengeluarkan sarinya. Sari tebu disiapkan 4 jam sebelum diberikan kepada subjek dan kemudian dimasukkan dalam botol dan didinginkan dalam lemari pendingin. Kelompok kontrol mendapatkan minuman berkarbohidrat pabrikan masing - masing sebanyak $550 \mathrm{ml}$ dengan kandungan karbohidrat $12.5 \mathrm{~g}$ karbohidrat yang terdiri dari $12 \mathrm{~g}$ sukrosa dan 0.5 gr fruktosa dan glukosa setelah latihan, dan kelompok perlakuan mendapatkan sari tebu murni masing masing sebanyak $550 \mathrm{ml}$ dengan kandungan $50 \mathrm{~g}$ karbohidrat yang terdiri dari $47.8 \mathrm{~g}$ sukrosa, 1.1 g glukosa dan $1.1 \mathrm{~g}$ fruktosa setelah latihan.

Variabel terikat pada penelitian ini adalah kadar glukosa darah atlet yang diukur mengunakan glukometer. Pengecekan kadar glukosa darah atlet ini dilaksanakan sebanyak 3 kali yaitu 5 menit sebelum pelaksanaan latihan, 5 menit setelah pelaksanaan latihan dan 15 menit setelah pemberian sari tebu untuk kelompok perlakuan dan pemberian minuman berkarbohidrat untuk kelompok kontrol. Kadar gula darah atlet diukur menggunakan glukometer.

Data yang dikumpulkan meliputi data berat badan, tinggi badan, dan persen lemak tubuh. Pengukuran berat badan diperoleh melalui penimbangan menggunakan timbangan injak digital dengan ketelitian $0,1 \mathrm{~kg}$. Pengukuran tinggi badan dilakukan dengan menggunakan microtoise dengan batas ukur $200 \mathrm{~cm}$ dan ketelitian $0,1 \mathrm{~cm}$. Persen lemak tubuh didapatkan melalui pengukuran dengan menggunakan Bioelectric Impedance Analyzer (BIA) injak.

Pengambilan data antopometri dan persen lemak tubuh dilakukan sebelum pelaksanaan Cooper Test untuk mengukur tingkat kebugaran (Tabel 1). Pengecekan kadar glukosa darah sebelum latihan dilakukan 5 menit sebelum pelaksaan latihan lari $2.4 \mathrm{Km}$. Pengecekan kadar glukosa darah setelah latihan dilakukan 5 menit setelah pelaksanaan latihan selesai, setelah dilakukan pengecekan kadar glukosa darah setelah latihan subjek menerima masing- masing perlakuan yaitu pemberian minuman karbohidrat pabrikan untuk kelompok kontrol dan pemberian sari tebu murni untuk kelompok perlakuan. Pengecekan kadar glukosa darah setelah intervensi dilakukan 15 menit setelah pemberian intervensi dilakukan.

Tabel 1. Kriteria tingkat kebugaran atlet laki-laki usia 13-19 tahun $^{31}$

\begin{tabular}{ll}
\hline Kriteria & Waktu tempuh (menit, detik) \\
\hline Baik sekali & $<09.40$ \\
Baik & $09.41-10.46$ \\
Cukup & $10.49-12.10$ \\
Kurang & $12.11-15.30$ \\
Kurang sekali & $>15.31$ \\
\hline
\end{tabular}

Analisis data dilakukan dengan menggunakan program komputer. Analisis univariate untuk mendeskripsikan karakteristik subjek penelitian yaitu usia, berat badan, tinggi badan, indeks massa tubuh dan persen lemak tubuh. Analisis bivariate diawali dengan uji kenormalan data dengan uji Shapiro-Wilk, didapatkan data berdistribusi normal maka perbedaan kadar glukosa darah sebelum latihan dan setelah latihan, perbedaan kadar glukosa darah setelah latihan dan setelah intervensi serta pernedaan kadar glukosa darah sebelum latihan dan setelah intervensi diuji dengan paired t test. Uji beda juga dilakukan pada kedua kelompok perlakuan. Perbedaan kadar glukosa darah sebelum latihan, setelah latihan, setelah intervensi dan selisih kadar glukosa darah 
setelah intervensi antara kelompok kontrol dan perlakuan diuji dengan Independent $t$ test.

\section{HASIL PENELITIAN}

Subjek penelitian merupakan atlet sepak bola berusia 13 - 16 tahun. Hasil analisis uji beda karakteristik subjek penelitian dari kelompok kontrol dan kelompok perlakuan disajikan dalam
Tabel 2. Berdasarkan hasil analisis tersebut ditunjukkan bahwa tidak terdapat perbedaan yang bermakna dari variabel usia, indeks masa tubuh (IMT) dan persen lemak tubuh pada kedua kelompok $\quad(p>0.05)$. Hal ini menunjukkan bahwa kedua kelompok memiliki karakteristik yang sama.

Tabel 2. Karakteristik subjek penelitian

\begin{tabular}{lllc}
\hline \multicolumn{1}{c}{ Karakteristik Subjek } & Kontrol $(\mathrm{n}=10)$ & Perlakuan $(\mathrm{n}=10)$ & \multirow{2}{*}{$P$} \\
\cline { 2 - 3 } & Rerata \pm SD & Rerata \pm SD & $0.690^{*}$ \\
Usia $($ Tahun) & $14.2 \pm 1.03$ & $13.9 \pm 0.31$ & $0.790^{* *}$ \\
IMT $\left(\mathrm{Kg} / \mathrm{m}^{2}\right)$ & $19.6 \pm 1.04$ & $19.7 \pm 0.92$ & $0.174^{* *}$ \\
\hline Kadar lemak tubuh $(\%)$ & $15.8 \pm 3.37$ & $13.2 \pm 4.72$ & 0 \\
\hline
\end{tabular}

*Mann-Whitney

**Independent t test

Perbedaan Kadar Glukosa darah Subjek Penelitian Sebelum Latihan, Setelah Latihan dan Setelah Intervensi

Hasil analisis uji beda kadar glukosa darah subjek 5 menit sebelum latihan, 5 menit setelah latihan dan 15 menit setelah intervensi disajikan pada Tabel 3. Berdasarkan hasil analisis tersebut didapatkan hasil perubahan glukosa darah sebelum latihan dan setelah latihan serta setelah latihan dan setelah intervensi pada masing - masing kelompok. Pada kelompok kontrol terdapat perbedaan yang signifikan baik antara kadar glukosa darah sebelum latihan dan setelah latihan maupun antara kadar glukosa darah setelah latihan dan setelah intervensi ( $\mathrm{p}<0.05)$. Pada kelompok perlakuan tidak terdapat perbedaan yang signifikan antara rerata kadar glukosa darah sebelum latihan dan setelah latihan $(\mathrm{p}$ $>0.05$ ). Terdapat perbedaan yang signifikan antara rerata kadar glukosa darah setelah latihan dan setelah intervensi pada kedua kelompok $(\mathrm{p}<0.05)$. Tidak terdapat perbedaan kadar glukosa darah antara sebelum latihan dan setelah intervensi pada kelompok kontrol sedangkan pada kelompok perlakuan terdapat perbedaan kadar glukosa darah antara sebelum latihan dan setelah intervensi.

Tabel 3. Perbedaan kadar glukosa darah sebelum latihan, setelah latihan dan setelah intervensi subjek penelitian masing - masing kelompok

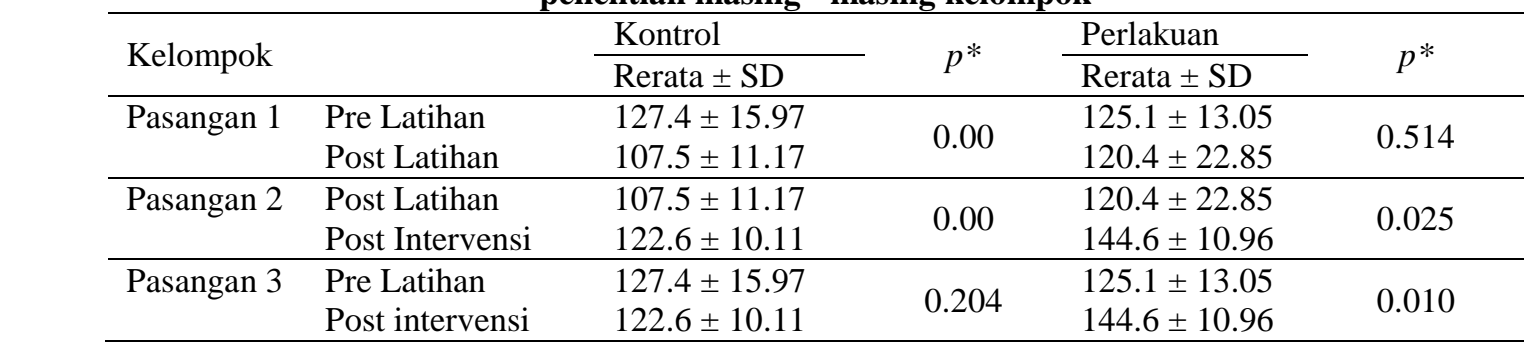

*paired t test

Perbedaan Kadar Glukosa darah Subjek Penelitian Sebelum Latihan, Setelah Latihan dan Setelah Intervensi Antar Kelompok

Hasil analisis uji beda antar kelompok kontrol dan perlakuan disajikan pada Tabel 2 . Berdasarkan hasil tersebut diketahui bahwa tidak terdapat perbedaan yang signifikan pada glukosa darah sebelum latihan dan setelah latihan antara kelompok kontrol dan perlakuan ( $p>0.05)$, sedangkan pada kadar glukosa darah setelah intervensi terdapat perbedaan yang signifikan antara kelompok perlakuan dan kontrol $(\mathrm{p}<0.05)$. Selisih kadar glukosa setelah latihan dan setelah intervensi pada masing masing kelompok adalah $15.10 \pm 8.69$ pada kelompok kontrol dan $24.20 \pm 28.61$ pada kelompok perlakuan. Tidak terdapat perbedaan yang bermakna secara statistik antara selisish kadar glukosa darah setelah latihan dan setelah intervensi antara kelompok kontrol dan perlakuan. 
Tabel 4. Perbedaan kadar glukosa darah sebelum latihan, setelah latihan dan setelah intervensi antar kelompok

\begin{tabular}{|c|c|c|c|}
\hline & \multicolumn{2}{|l|}{ кеiompoк } & \\
\hline \multirow{2}{*}{ Kelompok } & Kontrol & Perlakuan & \multirow{2}{*}{$p^{*}$} \\
\hline & Rerata $\pm \mathrm{SD}$ & Rerata $\pm \mathrm{SD}$ & \\
\hline Kadar glukosa darah sebelum latihan & $127.4 \pm 15.97$ & $125.1 \pm 13.05$ & 0.729 \\
\hline Kadar glukosa darah setelah latihan & $107.5 \pm 11.17$ & $120.4 \pm 22.85$ & 0.133 \\
\hline Kadar glukosa darah setelah intervensi & $122.60 \pm 10.11$ & $144.6 \pm 10.96$ & 0.000 \\
\hline $\begin{array}{l}\triangle \text { Kadar glukosa darah setelah latihan } \\
\text { dan setelah intervensi }\end{array}$ & $15.10 \pm 8.69$ & $24.20 \pm 28.61$ & 0.357 \\
\hline
\end{tabular}

\section{PEMBAHASAN}

Penelitian ini menggunakan subjek sebanyak 20 orang yang terbagi dalam dua kelompok. Kelompok kontrol berjumlah 10 subjek dan kelompok perlakuan berjumlah 10 subjek. Pada penelitian ini, pada seluruh subjek dilakukan pengukuran antopometri, persen lemak tubuh. Hasil uji beda menunjukkan tidak terdapat perbedaan bermakna dari hasil pengukuran antopometri dan persen lemak tubuh antar kelompok kontrol dan perlakuan $(\mathrm{p}>0.05)$. Tidak terdapatnya perbedaan yang bermakna pada tiap kelompok menunjukkan bahwa tiap kelompok dalam kondisi yang sama saat penelitian ini dilakukan.

Pada penelitian ini telah dilihat pengaruh konsumsi sari tebu yang mengandung 50 gr karbohidrat terhadap kadar gluksa darah atlet setelah latihan. Hasil analisis uji beda kadar glukosa darah sebelum latihan dan setelah latihan (paired $t$ test), menunjukkan bahwa terjadi penurunan kadar glukosa darah yang signifikan pada kelompok kontrol $(\mathrm{p}<0.05)$ sedangkan pada kelompok perlakuan tidak terjadi penurunan yang signifikan $(\mathrm{p}>0.05)$.

Kadar glukosa darah setelah latihan sangat dipengaruhi oleh intensitas latihan, asupan karbohidrat, simpanan glikogen hati dan glikogen otot sebelum latihan. Untuk menjaga fungsi tubuh kadar glukosa darah dalam tubuh akan selalu dipertahankan pada nilai normal, pada saat melakukan latihan dengan intensitas sedang sumber utama energi yang digunakan adalah glukosa, ketika kadar glukosa darah menurun simpanan glikogen tubuh akan dipecah menjadi glukosa. Simpanan glikogen hati dan otot yang cukup dapat menjaga kadar glukosa darah pada nilai normal. ${ }^{2,13}$ Seluruh subjek melakukan latihan yang sama yaitu lari 2.4 Km dalam waktu 10.49 - 12.10 menit, meskipun begitu tidak dilakukan pengukuran asupan karbohidrat, simpanan glikogen hati dan glikogen otot sebelum latihan sehingga tidak diketahui cadangan karbohidrat yang dimiliki masing masing subjek. Penurunan kadar glukosa darah setelah latihan yang tidak signifikan pada subjek kelompok perlakuan kemungkinan disebabkan oleh simpanan glikogen dalam tubuh yang cukup tinggi sehingga mampu mengatur kadar glukosa darah pada nilai yang lebih stabil.

Hasil analisis uji beda kadar glukosa darah setelah latihan dan setelah intervensi (paired t test), menunjukkan bahwa sari tebu dan minuman berkabohidrat pabrikan yang diberikan pada subjek secara signifikan meningkatkan kadar glukosa darah setelah latihan $(\mathrm{p}<0.05)$. Sari tebu maupun minuman berkarbohidrat pabrikan yang dikonsumsi pada penelitian ini memiliki kandungan jenis karbohidrat sederhana yang sama yaitu sukrosa, glukosa dan fruktosa yang dapat meningkatkan kadar gula darah atlet setelah latihan. Konsumsi cairan yang mengandung karbohidrat segera setelah latihan dapat menggantikan simpanan karbohidrat yang hilang setelah latihan lebih cepat dibandingkan bila konsumsi ditunda 2 jam setelah latihan. ${ }^{12}$ Penelitian lain menyebutkan bahwa penundaan asupan karbohidrat 2 jam setelah latihan dapat mengakibatkan penurunan pembentukan glikogen otot hingga $50 \% .^{5}$

Tidak terdapat perbedaan kadar glukosa darah antara sebelum latihan dan setelah intervensi pada kelompok kontrol sedangkan pada kelompok perlakuan terdapat perbedaan kadar glukosa darah antara sebelum latihan dan setelah intervensi. Nilai yang ditunjukkan pada hasil uji beda menyatakan bahwa konsumsi sari tebu lebih mampu mengembalikan kadar glukosa darah atlet dibandingkan dengan konsumsi minuman berkarbohidrat pabrikan.

Analisis uji beda kadar glukosa darah antara kelompok kontrol dan perlakuan menunjukkan hasil bahwa kadar glukosa darah sebelum latihan dan setelah latihan pada tiap kelompok tidak memiliki perbedaan yang signifikan ( $>0.05)$ dan pada kadar glukosa darah setelah intervensi terdapat perbedaan yang signifikan antara kelompok perlakuan dan kontrol $(\mathrm{p}<0.05)$. berdasarkan hasil tersebut diketahui bahwa kadar glukosa darah tiap kelompok hingga sebelum intervensi berada pada nilai yang sama, setelah intervensi dilakukan terjadi peningkatan kadar glukosa darah yang lebih tinggi pada kelompok perlakuan dibandingkan pada 
kelompok kontrol dengan perbandingan selisish peningkatan $24.20 \pm 28.61$ berbanding $15.10 \pm 8.69$, tetapi secara statistik tidak terdapat perbedaan yang signifikan antara peningkatan kadar glukosa darah pada kelompok kontrol dan perlakuan ( $\mathrm{p}>0.05)$.

Kadar glukosa darah setelah mengasup karbohidrat sangat dipengaruhi jumlah asupan karbohidrat, waktu konsumsi dan jenis karbohidrat. ${ }^{14}$ Waktu yang paling baik mengkonsumsi karbohidrat agar dapat menyediakan simpanan karbohidrat yang cukup adalah setelah latihan dan dengan mengkonsumsi karbohidrat sederhana. ${ }^{15}$ Tidak terdapat perbedaan pada waktu konsumsi karbohidrat pada tiap kelompok dan jenis karbohidrat yang dikonsumsi namun terdapat perbedaan jumlah asupan karbohidrat. Pada kedua kelompok $550 \mathrm{ml}$ sari tebu dan minuman karbohidrat pabrikan yang dikonsumsi mengandung sebagian besar berupa sukrosa dengan sedikit glukosa dan fruktosa, namun jumlah karbohidrat total pada sari tebu berjumlah 50 $\mathrm{g}$ dan pada miniman berkarbohidrat pabrikan berjumlah 12.5 g. ${ }^{10,16,17}$ Kandungan keduanya lebih tinggi dibandingkan kemampuan tubuh dalam menyimpan glukosa, yakni hanya sebesar 5 gram atau setara dengan 20 kalori. ${ }^{13}$

Waktu konsumsi dan jenis karbohidrat yang sama dapat diartikan bahwa tingkat penyerapan karbohidrat didalam tubuh memiliki nilai yang sama. ${ }^{18,5}$ Perbedaan jumlah asupan menjadi hal yang sangat berpengaruh pada kadar glukosa darah. Kadar glukosa darah diatur dalam kisaran yang sempit, setelah konsumsi karbohidrat kadar glukosa darah akan dipertahankan dalam kisaran $117 \mathrm{mg} / \mathrm{dl}$ - $129.2 \mathrm{mg} / \mathrm{dl}$. Kadar glukosa darah dalam tubuh akan selalu dijaga dalam keadaan normal, peningkatan kadar glukosa darah yang melebihi kisaran tersebut setelah mengasup karbohidrat akan memicu hormon insulin bekerja secara aktif menurunkan kadar glukosa darah hingga berada pada nilai normal. semakin tinggi kadar glukosa darah setelah mengasup karbohidrat, hormon insulin juga akan semakin aktif untuk menjaga kadar glukosa darah berada dalam kisaran normal. ${ }^{21}$

Kandungan $50 \mathrm{~g}$ karbohidrat pada sari tebu yang dikonsumsi mampu memenuhi kebutuhan minimal atlet untuk 2 jam pertama setelah latihan sedangkan $12.5 \mathrm{~g}$ karbohidrat yang terkandung pada minuman berkarbohidrat pabrikan yang dikonsumsi hanya mampu memenuhi seperempat dari kebutuhan minimal atlet untuk 2 jam pertama. ${ }^{17}$ Sebuah penelitian menyebutkan setelah latihan terjadi peningkatan transport glukosa yang membantu proses resintesis glikogen, namun akan menurun secara cepat jika tidak ada asupan karbohidrat. Tersedianya asupan karbohidrat yang cukup segera setelah latihan tubuh akan mampu mengembalikan ketersediaan karbohidrat dalam tubuh atlet dengan cepat. ${ }^{6,7}$ Selain kandungan karbohidrat yang secara alami lebih tinggi dibandingkan minuman karbohidrat pabrikan, sari tebu juga mengandung berbagai vitamin dan mineral serta memiliki sifat sebagai antioksidan yang baik karena kandungan fenol dan flavonoid nya.

Minuman karbohidrat pabrikan memiliki kandungan elektrolit yang lebih seimbang dibandingkan sari tebu, namun minuman karbohidrat pabrikan juga mengandung bahan pengawet berupa natrium benzoate, asam sitrat dan asam askorbat yang walaupun berada pada jumlah yang diperbolehkan akan tetap menimbulkan resiko bila dikonsumsi dalam jumlah besar dan terus menerus. Minuman berkarbohidrat pabrikan juga memiliki sifat yang lebih asam dibandingkan minuman karbohidrat alami sehingga beresiko merusak gigi bila dikonsumsi secara sering dan terus menerus. ${ }^{16,22}$

Keterbatasan dalam penelitian ini adalah tidak dilakukannya pengukuran terhadap simpanan glikogen hati dan otot sebelum latihan dan setelah intervensi pada subjek penelitian. Tidak dilakukannya pengukuran terhadap kedua hal tersebut sebelum latihan menyebabkan efek latihan yang diberikan terhadap kadar glukosa darah tidak dapat dikontrol dan tidak dilakukannya pengukuran pada kedua hal tersebut setelah intervensi menyebabkan tidak dapat diketahuinya efek sebenarnya dari intervensi terhadap simpanan karbohidrat tubuh.

\section{SIMPULAN}

Konsumsi sari tebu murni dan minuman berkarbohidrat pabrikan setelah latihan mampu meningkatkan kadar lukosa darah atlet setelah latihan masing - masing sebesar $24.2 \pm 28.61$ dan $15.10 \pm 8.69$. Sari tebu mampu meningkatkan kadar glukosa darah atlet sebanding dengan minuman berkarbohidrat pabrikan dengan $(\mathrm{p}>0.05)$. Sari tebu dapat digunakan sebagai alternatif minuman sumber karbohidrat selain minuman berkarbohidrat pabrikan.

\section{SARAN}

Diperlukan pemeriksaan kadar glikogen otot dan hati sebelum latihan dan setelah intervensi. Diperlukan penelitian lebih lanjut dalam modifikasi komposisi sari tebu sehingga bisa menjadi alternatif minuman sumber karbohidrat alami yang lebih optimal. Pemberian sari tebu dengan kandungan 50 
g karbohidrat dapat diterapkan pada atlet sebagai sumber asupan karbohidrat setelah latihan dengan intensitas sedang untuk menggantikan simpanan karbohidrat dalam tubuh.

\section{DAFTAR PUSTAKA}

1. Coyle EF. Fluid and Fuel Intake During Exercise. Journal of Sports Sciencs. [serial online] 2004 [dikutip 2011 Jan 25]; [17 halaman]. Tersedia URL: www.uni.edu/dolgener/Advanced_Sport_Nutrition Ifluid intake.pdf

2. Heater HF, Lisa AB, Alan EM. Practical application in sports nutrition. Massachusetts: Jones and Bartlett Publisher; 2006.p.82-83; 224-6; 326; 434; 470-5.

3. Andersen GD. Understanding Fluid, Electrolyte, and Carbohydrate Replacement During Activity. Natural Medicine Journal [serial online] 1998 Nov [cited 2013 july 14];[11 screens]. Available from: http://www.andersenchir.com/understanding-fluidreplacement.html.

4. Charney, Pamela. Water, Electrolytes, and AcidBase Balance. Dalam: Mahan LK, Escott-Stump S,editor. Krause's food, nutrition and diet therapy. Elsevier; Canada. $2008: 12^{\text {th }}$ ed.

5. Jenjents R, Jeukendrup A. Determinants of post exercise glycogen synthesis during short-term recovery. Sports Med. 2003; 33:117

6. Cartee GD, Young DA, Slepper MD, Zierath J, Wallberg-Henriksson H, Holloszy JO. Prolonged increase in insulin-stimulated glucose transport in muscle after exercise. Am J Physiol. 1989; 256.

7. Goodyear LJ, Hirshman MF, King PA, Horton ED, Thompson CM, Horton ES. Skeletal muscle plasma membrane glucose transport and glucose transport after exercise. J Appl Physiol. 1990; 68: 193- 8

8. Irawan, M. Anwari. Konsumsi Cairan dan Olahraga. Polton Sports Science and Performance Lab. 2007: Vol1.

9. Sizer FS, Ellie W. Nutrition Concepts And Controversies. 10th Ed. USA : Thomson Wadsworth; 2006. p. 359-92.

10. Kalpana K, Lal PR, Kusuma DK, Khanna GL. The effects of ingestion of sugarcane juice and commercial sports drink on cycling performance of athletes in comparison to plain water. Asran $\mathrm{j}$ Sports Med 2013; 04 (No x) xxx.

11. Shirreffs SM, Watson P, Maughan RJ.Milkas an effective post-exercise rehydration drink. British Journal of Nutrition.2007; $98: 173-80$.

12. Piehl AK, Soderlund K, Hultman E, Muscle glycogen resynthesis rate in humans after supplementation of drinks containing carbohydrates with low and high molecular masses.Eur J Appl Physiol. 2000 ; 81(4) : 346

13. Willam MH. Nutrition for health, finess, and sport. $8^{\text {th }}$ edition. New York: Mc graw-Hiil Companies, inc; 2007.p.118-120; 122; 124; 125; 128; 129; 131.

14. Matthew,L. Goodwin. Blood Glucose Regulation during Prolonged, Submaximal, Continuous
Exercise: A Guide for Clinicians, 2010; 4 (3) 694702.

15. Dorfman L. Nutrition for exercise and sports performance. In: Mahan LK, Sylvia Escott-Stump S, editors. Krause's food, nutrition, \& diet therapi. 12 th ed. Philadelphia: Saunders Elsevier, Inc; 2012.p. 508-13.

16. Anonymous. Fact Sheet Sport Drink. Sport Dietitians Australia. 2009

17. Kuswurj, Risvan. Komposisi Nira Tebu dan Pengaruhnya Dalam Proses Pengolahan Gula. Sugarcane Processing and Technology. [serial online] 20011 [dikutip 2014 Jul 7]; [1 halaman]. Tersedia URL: http://www.risvank.com/2011/11/29/komposisi nira tebu dan pengaruhnya -dalam-prosespengolahan-gula/

18. Casey A. Mann R, Banister K, Fox J, Morris PG, Macdonald IA, et al. Effect of Carbohydrate Ingestion on Glycogen Resynthesis in Human Liver and Skeletal Muscle, Measured by 13C MRS. AM J Physiol 2000; 278; E 65-75

19. Widjaja E, Toharmat T, Santoso DA, Sumiati, Ridla M, Iskandar S. Potensi nira tebu sebagai suplemen cair dan karier enzim fitase untuk unggas secara in vitro. 2011. JITV 16(4) : 272- 79

20. Kadam US, Ghosh SB, DE Strayo, Suprasanna P, Devasagayam TPA, Bapat VA. Antioxidant activity in sugarcane juice and its protective role against radiation induced DNA damage. 2008. Food Chemistry. 106 (3) : 1154- 60

21. Bender DA, Mayes PA. Glukoneogenesis and The Control of Blood Glucose. In : Murray RK, Granner DK, Rodwell VW, editors. Harper's Illustrated Biochemistry. 27th ed. China: McGraw - Hill Companies Inc. 2006.p. 174

22. RF Laila, Resmi S. Analisis Kandungan Bahan Pengawet Dalam Produk- produk Minuman Kemasan Yang Ada di Pasaran Untuk Menjaga Keamanan Pangan Masyarakat.2009.Universitas Diponegoro. 